\title{
CLASSIFICATION AND REGRESSION TREE (CART) DALAM KLASIFIKASI KEMANDIRIAN HIDUP BERDASARKAN KONDISI KESEHATAN LANSIA DI KELURAHAN KASIN WILAYAH KERJA PUSKESMAS BARENG KOTA MALANG \\ Classification And Regression Tree (Cart) In Classification Of Independence Of Life Based On Elderly Health Conditions In Working Area Perifer Hospital of Bareng Malang City
} Wisoedhanie Widi Anugrahanti. ${ }^{1}$, Oda Debora ${ }^{2}$, Berliany Venny Sipollo. ${ }^{3}$

1. DIII Keperawatan (STIKes Panti Waluya Malang, wisoedhanie.widi@gmail.com)

2. Prodi S1 Keperawatan (STIKes Panti Waluya Malang, katarina29debora@gmaol.com 3. Prodi Profesi Ners (STIKes Panti Waluya, berlianyvenny@ rocketmail.com)

\begin{abstract}
ABSTRAK
Latar belakang:Lansia harus mampu beradaptasi dengan semua perubahan-perubahan yang terjadi dalam kehidupannya. Kemampuan lansia untuk beradaptasi dengan perubahan hidup dapat membantu menurunkan angka Dependency Ratio. Dependency Ratio dapat diminimalkan melalui tercapainya kemandirian hidup lansia. Kondisi kesehatan merupakan salah satu faktor yang berkaitan erat dengan kemampuan lansia untuk hidup secara mandiri di masa tuanya.
\end{abstract}

Tujuan: Penelitian ini bertujuan untuk mengidentifikasi klasifikasi kemandirian hidup lansia di Kelurahan Kasin Wilayah Kerja Puskesmas Bareng Kota Malang melalui pendekatan kondisi kesehatan.

Metode: Berdasarkan waktu penelitian ini tergolong crossectional dengan responden lansia berusia 60 tahun ke atas di Kelurahan Kasin wilayah kerja Puskesmas Bareng Kota Malang sejumlah 142 yang diperoleh melalui multistage random sampling. Instrumen yang digunakan IADL, sfigmomanometer, Snellen test, Abbreviated Mentaltest (AMT), Geriatric Depression Scale (GDS), beserta kuesioner identifikasi kondisi dan persepsi lansia terhadap kondisi kesehatannya. CART digunakan untuk klasifikasi kemandirian lansia dengan software Salfold Predictive Modeller.

Hasil: Hasil klasifikasi menunjukkan sejumlah 78,2\% lansia tergolong mandiri, dengan karakteristik memiliki menu makan harian tertentu, memiliki fungsi pendengaran normal atau ada gangguang, memiliki persepsi kesehatan saat ini lebih baik, memiliki gangguan muskuloskeletal, dan tidak mengonsumsi obat. Pemilah terbaik berdasarkan nilai goodness of split adalah menu harian yang dikonsumsi lansia 0,1125041, persepsi kesehatan saat ini 0,0813413, fungsi pendengaran 0,0652887, Gangguan muskuloskeletal 0,0204411, konsumsi obat 0,0002492 . Nilai akurasi yang diperoleh $69,72 \%$, nilai sensitivity $71,17 \%$ dan nilai specificity $64,52 \%$.

Kesimpulan: Menu harian yang dikonsumsi lansia dan persepsi terhadap kesehatan saat ini merupakan variabel utama yang berkontribusi dalam klasifikasi kemandirian hidup lansia. Variabel lain yang juga memberikan kontribusi adalah persepsi kesehatan saat ini, fungsi pendengaran, gangguang muskuloskeletal yang dialami lansia dan konsumsi obat.

Keyword: CART, Kondisi Kesehatan, Kemandirian Lansia

\section{ABSTRACT}

Backgraund: The elderly must be able to adapt to all the changes that occur in their lives. The ability of the elderly to adapt to life changes can help reduce the Dependency Ratio. Dependency Ratio can be minimized through achieving the independence of life of the elderly. 
Health condition is one of the factors that is closely related to the ability of the elderly to live independently in their old age.

Aim : This study aims to identify the elderly in the independence of their lives in Kelurahan Kasin Peripheral Hospital of Bareng Malang, through the health condition approach

Method: Based on the time of this study, it is classified as cross-sectional with elderly respondents aged 60 years and over in Kasin Kelurahan, a total of 142 obtained through the multistage random sampling. The instruments used were IADL, sphygmomanometer, Snellen test, Abbreviated Mentaltest (AMT), Geriatric Depression Scale (GDS), along with questionnaires to identify conditions and the perception of the elderly towards their health conditions. CART is used for the classification of independence of the elderly with the Salfold Predictive Modeller software

Results: The classification results showed that $78.2 \%$ of the elderly were independent, characterized by having a certain daily diet, having normal hearing function or having an impairment, having better health perception, having musculoskeletal disorders, and not taking drugs. The best sorting based on the value of goodness of split is the daily menu consumed by the elderly 0.1125041, current health perception 0.0813413, hearing function 0.0652887, musculoskeletal disorders 0.0204411, drug consumption 0.0002492. The accuracy value obtained is $69.72 \%$, sensitivity value is $71.17 \%$ and specificity value is $64.52 \%$

Conclusion :Daily menu consumed by the elderly and current perception of health are variables that contribute to the independence of the elderly based on health conditions, while the use of stairs, daily physical activity, home improvement is a functional capacity that contributes to the independence of the elderly.

Keyword: CART, Health Conditions, Independence of the Elderly

\section{PENDAHULUAN}

Indonesia saat ini berdasarkan pertumbuhan penduduknya berada pada tahap Ageing population yaitu fenomena yang terjadi ketika umur median penduduk dari suatu negara mengalami peningkatan karena bertambahnya tingkat harapan hidup atau menurunnya tingkat fertilitas (UN, 2015). Penurunan angka fertilitas, mortalitas serta peningkatkan angka harapan hidup yang merupakan konsekuensi dari meningkatnya gizi masyarakat, perbaikan sanitasi, meningkatnya pemerataan pelayanan kesehatan, hingga kemajuan tingkat pendidikan dan sosial ekonomi yang mengubah struktur penduduk secara keseluruhan merupakan faktor yang berkontribusi dalam perubahan komposisi penduduk Indonesia (Pusdatin Lansia, 2017).

Ageing Population merupakan isu dan masalah yang krusial di Indonesia. Besarnya jumlah penduduk lanjut usia akan membawa dampak positif apabila penduduk lansia berada dalam keadaan sehat, aktif dan produktif, dan akan memberikan dampak negatif apabila lanjut usia memiliki masalah penurunan kesehatan yang berakibat pada peningkatan biaya pelayanan kesehatan, penurunan pendapatan atau penghasilan, peningkatan disabilitas, tidak adanya dukungan sosial dan lingkungan yang tidak ramah terhadap penduduk lansia yang pada akhirnya meningkatkan dependency ratio (Pusdatin Lansia, 2017).

World Population Prospect memprediksikan bahwa penduduk lansia di Indonesia pada tahun 2020 sebesar 20,08 juta jiwa, pada tahun 2025 sebesar 33,65 juta jiwa, pada tahun 2030 sebesar 40,95 juta jiwa, dan pada tahun 2035 sebesar 48,19 juta jiwa (Pusdatin Lansia, 2017). Tiga propinsi di Indonesia dengan jumlah lansia terbesar adalah DI Yogyakarta $(13,81 \%)$, Jawa tengah $(112,59 \%)$ dan Jawa Timur (12,25\%) (Pusdatin Lansia, 2017). Kondisi kesehatan lansia pada tahun 2015 menunjukkan bahwa angka kesakitan lansia di Indonesia 
sebesar 28,62\%, dengan angka kejadian di pedesaan lebih tinggi yaitu sebesar 30,14\% dibandingkan perkotaan yaitu $26,89 \%$. Rasio ketergantungan penduduk lansia Indonesia pada tahun 2015 sebesar 13,28\% artinya bahwa setiap 100 penduduk usia produktif akan menanggung sekitar 14 orang penduduk lansia (Susenas, 2015)

Profesional perawatan kesehatan dalam setiap layanan kesehatan berkepentingan untuk mengevaluasi situasi individu lansia dalam arti yang luas yang mendukung kehidupan mandiri diantaranya kesehatan, kapasitas fungsional, sumber daya, atribut pribadi, lingkungan hidup dan lingkungan. Kesehatan dan kapasitas fungsional adalah faktor yang paling berkaitan erat dengan kemandirian hidup pada lansia. (Bravell et al, 2007; Beswick et al, 2010).

Identifikasi kondisi kesehatan lansia merupakan salah satu pendekatan yang dapat digunakan dalam klasifikasi kemandirian lansia. Identifikasi kondisi kesehatan yang berkontribusi dalam kemandirian lansia sangat berguna bagi praktisi kesehatan khususnya keperawatan, untuk mempelajari hal-hal baru atau metode baru yang dapat diberikan bagi lansia dalam upaya meningkatkan kondisi kesehatan lansia, guna meningkatkan kemandirian lansia dan menurunkan dependency ratio (Ahlqvist, 2016).

Klasifikasi kemandirian hidup melalui pendekatan kondisi kesehatan lansia dapat dilakukan dengan mengaplikasikan metode klasifikasi non parametrik Classification And Regression Tree (CART). CART merupakan metode Machine Learning dimana metode eksplorasi data dilakukan dengan teknik pohon keputusan. CART menerapkan algoritma penyekatan rekursif biner dimana pemilah dilakukan pada sekelompok data yang terkumpul dalam satu ruang yang disebut simpul/node menjadi dua simpul anak (Lewis, 2000). Keunggulan metode CART diantaranya; mampu mengeksplorasi data berdimensi tinggi menggunakan komputasi yang efisien, mampu diaplikasikan pada data kontinu dan kategori, mampu mengeksplorasi variabel yang sangat banyak, penghitungannya lebih cepat dengan interpretasi yang lebih mudah (Timofeev, 2004 dalam Muttaqin, 2013).

Puskesmas Bareng merupakan layanan kesehatan masyarakat dibawah naungan Dinas Kesehatan Kota Malang. Puskesmas Bareng berdiri pada tahun 1982, berdasarkan Inpres tahun 1975 yang terletak di Jl.Bareng Tenes gang IV A nomor 639 Malang. Puskesmas Bareng memiliki wilayah kerja meliputi: Kelurahan Bareng, Kelurahan Gadingkasri, Kelurahan Kasin, dan Kelurahan Sukoharjo. Hasil studi pendahuluan yang dilakukan oleh peneliti pada bulan Februari 2018 melalui wawancara yang dilakukan kepada salah satu pembimbing klinik di Puskesmas Bareng diperoleh data bahwa belum dimilikinya data tentang klasifikasi kemandirian lansia ditinjau dari pendekatan kondisi kesehatan lansia di Kelurahan Kasin wilayah kerja Puskesmas Bareng Kota Malang. Pada penelitian ini peneliti tertarik untuk menerapkan metode Classification And Regression Tree (CART) dalam identifikasi klasifikasi kemandirian hidup lansia melalui pendekatan 21varibel prediktor kondisi kesehatan pada lansia di Kelurahan Kasin Puskesmas Bareng Kota Malang.

\section{METODE}

Ditinjau dari waktu, penelitian ini adalah cross sectional yaitu penelitian yang mengidentifikasi informasi pada banyak kasus pada satu titik waktu. (Kuntoro, 2011). Berdasarkan jenis analisanya penelitian ini juga tergolong sebagai penelitian multivariat karena menggunakan multivariabel sebagai prediktor untuk dianalisa secara bersamaan (Kuntoro, 2014). Penelitian ini mengelaborasi kondisi kesehatan lansia untuk memprediksi klasifikasi kemandirian hidup lansia menjadi kategori mandiri dan ketergantungan/tidak mandiri melalui 
pendekatan 21 variabel kondisi kesehatan dengan mengaplikasikan metode klasifikasi non parametrik Classification And Regression Tree (CART). Penelitian ini dilakukan di Kelurahan Kasin Wilayah Kerja Puskesmas Bareng Kota Malang. Pengambilan data pada bulan Mei 2019 sampai dengan Juli 2019. Yang menjadi populasi dalam penelitian ini adalah lansia yang bertempat tinggal di Kelurahan Kasin Wilayah Kerja Puskesmas Bareng Kota Malang. Sampling menggunakan multistage random sampling dan didapatkan sejumlah 142 sampel. Variabel prediktor adalah kondisi kesehatan lansia yang dijabarkan dalam 21 variabel prediktor. Kemandirian lansia sebagai variabel respon diukur menggunakan Instrumental Activity Daily Living (IADL), untuk data tentang kondisi kesehatan lansia tentang pengukuran TD secara obyektif dilakukan pengukuran melalui sfigmomanometer, untuk fungsi pengelihatan diidentifikasi melalui snellen test, penghitungan IMT, AMT tes untuk pengukuran fungsi kognitif dan GDS untuk pengukuran resiko depresi pada lansia.

\section{HASIL}

Berikut disajikan hasil penelitian yang meliputi karakteristik responden, hasil klasifikasi kemandirian hidup lansia beserta variabel kondisi kesehatan yang berkontribusi, dan hasil akurasi klasifikasi kemandirian hidup lansia melalui perhitungan APER, sensitivity, specificity.

Karakteristik demografi lansia pada penelitian ini meliputi usia lansia, jenis kelamin lansia, dan karakteristik kondisi kesehatan lansia yang memberikan kontribusi dalam klasifikasi kemandirian hidup lansia meliputi menu harian yang dikonsumsi lansia, persepsi kesehatan lansia, fungsi pendengaran lansia, gangguan muskuloskeletal yang dialami lansia, konsumsi obat lansia seperti yang tertuang pada tabel 1 berikut:

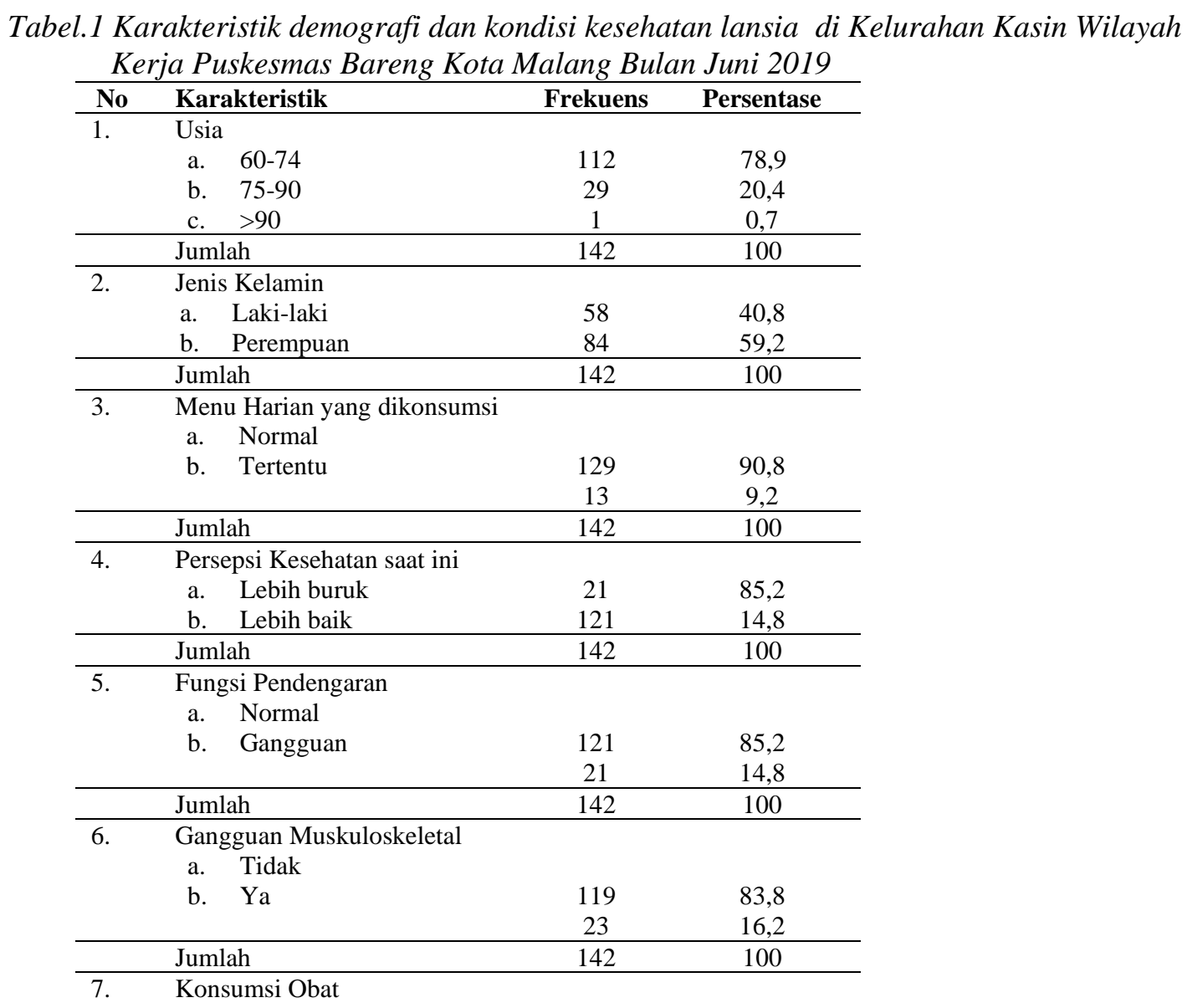




\begin{tabular}{llcc}
\hline No & Karakteristik & Frekuens & Persentase \\
\hline & a. Tidak & 103 & 72,5 \\
& b. Ya & 39 & 27,5 \\
\hline \multicolumn{2}{l}{ Jumlah } & 142 & 100 \\
\hline \multicolumn{2}{l}{ Sumber: data primer penelitian } &
\end{tabular}

Pada tabel 1 diperoleh data, berdasarkan usia didapatkan bahwa dari 142 lansia, sejumlah 79\% atau sebanyak 112 lansia berusia 60-74 tahun dan sejumlah 0,7\% atau 1 lansia berusia $>90$ tahun. Berdasarkan jenis kelamin diperoleh dari 142 lansia, sejumlah $59 \%$ atau sebanyak 84 lansia berjenis kelamin perempuan dan sejumlah $41 \%$ atau 58 lansia berjenis kelamin laki-laki. Kebiaasaan menu harian yang dikonsumsi lansia diperoleh bahwa dari 142 lansia, sejumlah 90,8\% atau sebanyak 129 lansia memiliki menu harian normal dan sejumlah 9,2\% lansia atau 13 memiliki menu harian tertentu. Persepsi kesehatan diperoleh bahwa dari 142 lansia, sejumlah 85,2\% atau sebanyak 121 lansia memiliki persepsi lebih baik atas kondisi kesehatannya saat ini dan sejumlah 14,8\% lansia atau 21 memiliki persepsi buruk. Berdasarkan fungsi pendengaran dari 142 lansia, sejumlah 85,2\% atau sebanyak 121 lansia memiliki fungsi pendengaran normal dan sejumlah 14,8\% lansia atau 21 lansia memiliki fungsi pendengaran terganggu. Gangguan muskuloskeletal yang dialami lansia diperoleh dari 142 lansia, sejumlah $83,80 \%$ atau sebanyak 119 lansia memiliki tidak mengalami gangguan muskuloskeletal dan sejumlah 14,8\% lansia atau 23 lansia memiliki gangguan muskuloskeletal. Kebiasaan mengkonsumsi obat, diperoleh data dari 142 lansia, sejumlah 72,50\% atau sebanyak 103 lansia tidak sedang mengkonsumsi obat secara rutin dan sejumlah $27,5 \%$ lansia atau 39 lansia mengkonsumsi obat secara rutin.

Hasil goodness of split, menunjukkan bahwa dari 21 varibel kondisi kesehatan yang merupakan variabel prediktor, terdapat sejumlah 5 variabel yang memberikan kontribusi terhadap kemandirian hidup lansia berdasarkan nilai goodness of splitnya. Berikut adalah 5 variabel prediktor dari 21 variabel prediktor kondisi kesehatan yang berkontribusi dalam klasifikasi kemandirian hidup berdasarkan hasil nilai goodness of split variabel tersebut seperti terlihat pada tabel 2 berikut;

Tabel.2 Variabel kontributor dalam Klasifikasi Kemandirian Hidup Lansia

\begin{tabular}{|l|l|l|c|}
\hline \multicolumn{1}{|c|}{ Nama Variabel } & \multicolumn{1}{|c|}{ Kategori } & Skala & Goodness of Split \\
\hline Menu harian & $\begin{array}{l}\text { 1: Normal } \\
\text { 2: Tertentu }\end{array}$ & Nominal & 0,1125041 \\
\hline $\begin{array}{l}\text { Persepsi Kesehatan saat ini } \\
\text { dibandingkan yang lalu }\end{array}$ & $\begin{array}{l}\text { buruk } \\
\text { 2:Lebih baik }\end{array}$ & Nominal & 0,0813413 \\
\hline Fungsi pendengaran & $\begin{array}{l}1: \text { Normal } \\
\text { 2: Gangguan }\end{array}$ & Nominal & 0,0652887 \\
\hline Gangguan muskuloskeletal & $\begin{array}{l}1: \text { Tidak } \\
\text { 2: Ya }\end{array}$ & Nominal & 0,0204411 \\
\hline Konsumsi obat & $\begin{array}{l}1: \text { Tidak } \\
2: \text { Ya }\end{array}$ & Nominal & 0,0002492 \\
\hline
\end{tabular}

Sumber: data primer penelitian

\section{Hasil analisis Classification And Regression Tree (CART)}

Hasil analisis CART menunjukkan klasifikasi kemandirian hidup lansia bahwa dari 142 lansia, sejumlah 78,20\% atau sebanyak 111 lansia tergolong dalam kategori mandiri dan sejumlah 21,80\% lansia atau 31 lansia tergolong dalam kategori tidak mandiri, seperti terlihat pada diagram pie 1 sebagai berikut: 


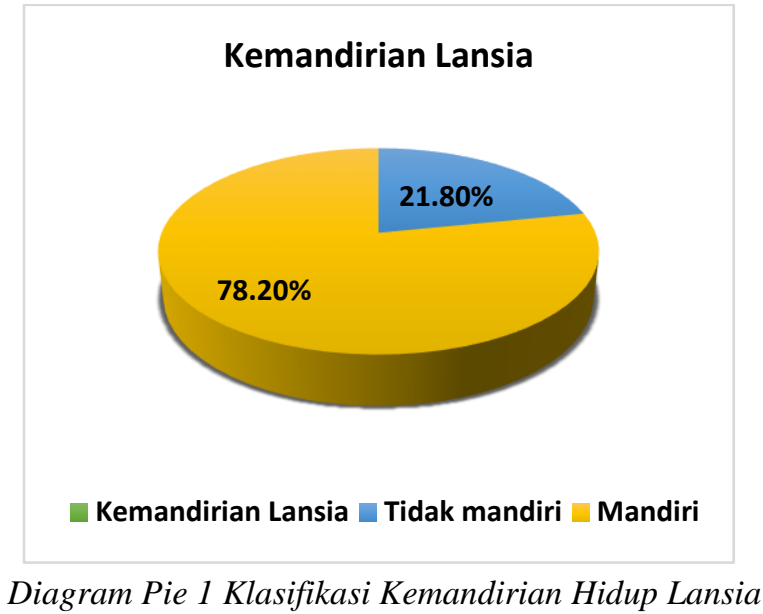

Pada analisis CART pohon optimal yang terbentuk ditunjukkan sesuai nilai yang tertera pada hasil relative cost minimum yang merupakan dasar pembentukan klasifikasi pohon optimal pada kemandirian hidup lansia seperti yang ditunjukkan pada tabel 3 berikut:

Tabel.3 Nilai Relative Cost Minimum Pada Pembentukan Pohon Klasifikasi Optimum

\begin{tabular}{lllrr}
\hline $\begin{array}{l}\text { Tree } \\
\text { Number }\end{array}$ & $\begin{array}{l}\text { Terminal } \\
\text { Nodes }\end{array}$ & $\begin{array}{l}\text { Test Seet } \\
\text { Relative Cost }\end{array}$ & $\begin{array}{l}\text { Resubstitution } \\
\text { Relative Cost }\end{array}$ & $\begin{array}{l}\text { Complexity } \\
\text { Parameter }\end{array}$ \\
\hline 1 & 11 & $0,72043 \pm 0,09826$ & 0,22668 & 0,000000 \\
\hline 2 & 10 & $0,69340 \pm 0,09781$ & 0,23569 & 0,004526 \\
\hline 3 & 9 & $0,65214 \pm 0,09626$ & 0,24615 & 0,005241 \\
\hline 4 & 8 & $0,66115 \pm 0,09643$ & 0,26417 & 0,009019 \\
\hline $5^{* *}$ & 6 & $0,64313 \pm 0,09609$ & 0,31822 & 0,013524 \\
\hline 6 & 4 & $0,70910 \pm 0,09812$ & 0,38419 & 0,016502 \\
\hline 7 & 3 & $0,72857 \pm 0,09654$ & 0,50044 & 0,058133 \\
\hline 8 & 2 & $0,74048 \pm 0,08707$ & 0,62191 & 0,060748 \\
\hline 9 & 1 & $1,00000 \pm 0,00000$ & 1,00000 & 0,189054 \\
\hline
\end{tabular}

Berdasarkan nilai relative cost minimum tersebut diperoleh bahwa dalam proses pembentukan pohon klasifikasi kemandirian hidup lansia diperoleh pohon optimal pada pembentukan pohon kelima dengan jumlah simpul terminal sejumlah 6 seperti terlihat pada gambar.1 sebagai berikut:

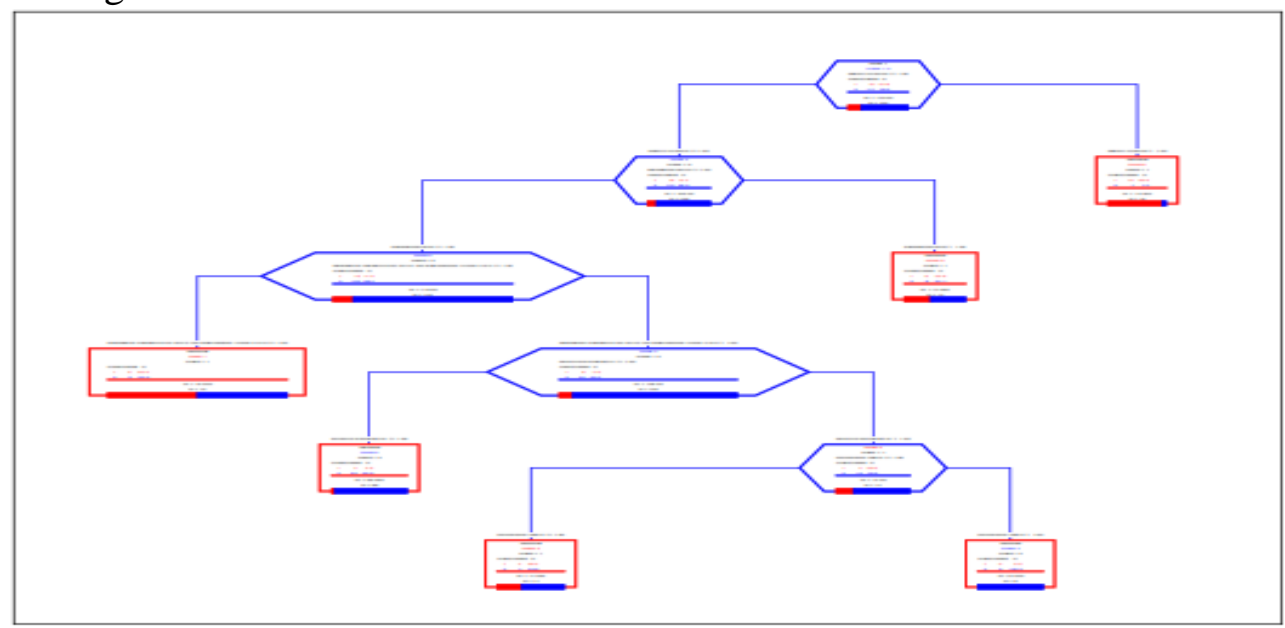

Gambar.1 Pohon Optimal pada Klasifikasi Kemandirian Hidup Lansia 
Gambar 1 menunjukkan hasil klasifikasi kemandirian berdasarkan simpul terminal yang menggambarkan karakteristik lansia sebagai berikut:

1. Simpul terminal 1 terdiri dari 10 lansia yang diprediksi sebagai lansia tidak mandiri. Karakteristik lansia pada simpul ini adalah memiliki menu makan harian normal, memiliki fungsi pendengaran normal, memiliki persepsi kesehatan saat ini lebih buruk dibandingkan yang lalu.

2. Simpul terminal 2 terdiri dari 88 lansia yang diprediksi sebagai lansia mandiri. Karakteristik lansia pada simpul ini adalah memiliki menu harian tertentu, memiliki fungsi pendengaran normal, memiliki persepsi kesehatan saat ini lebih baik dibandingkan yang lalu, memiliki gangguan muskuloskeletal

3. Simpul terminal 3 terdiri dari 11 lansia yang diprediksi sebagai lansia tidak mandiri. Karakteristik lansia pada simpul ini adalah memiliki menu harian normal, memiliki gangguan fungsi pendengaran, memiliki persepsi kesehatan lebih buruk dibandingkan yang lalu, mengalami gangguan muskuloskeletal, mengkonsumsi obat

4. Simpul terminal 4 terdiri dari 6 lansia yang diprediksi sebagai lansia mandiri. Karakteristik lansia pada simpul ini adalah memiliki menu harian tertentu, memiliki gangguan fungsi pendengaran, memilik persepsi kesehatan lebih baik dibandingkan yang lalu, mengalami gangguan muskuloskeletal, tidak mengkonsumsi obat

5. Simpul terminal 5 terdiri dari 14 lansia yang diprediksi sebagai lansia tidak mandiri. Karakteristik lansia pada simpul ini adalah memiliki menu harian normal, memiliki fungsi pendengaran normal

6. Simpul terminal 6 terdiri dari 13 lansia yang diprediksi sebagai lansia tidak mandiri.

Karakteristik lansia pada simpul ini adalah memiliki menu harian normal.

Karakteristik Kemandirian Lansia

Berikut karakteristik klasifikasi kemandirian hidup lansia dengan kategori mandiri dan ketergantungan/tidak mandiri dapat dilihat pada tabel 4 sebagai berikut:

\section{Tabel.4 Karakteristik Klasifikasi Kemandirian Hidup Lansia Berdasarkan Kategori} Mandiri dan Ketergantungan

Lansia dengan Ketergantungan/Tidak Lansia Mandiri
Mandiri

1. Memiliki menu makan harian normal, memiliki fungsi pendengaran normal, memiliki persepsi kesehatan lebih buruk

2. Memiliki gangguan fungsi pendengaran, mengalami gangguan muskuloskeletal, mengkonsumsi obat

1. Memiliki menu makan harian tertentu, memiliki fungsi pendengaran normal, memiliki persepsi kesehatan lebih baik, memiliki gangguan muskuloskeletal

2. Memiliki gangguan fungsi pendengaran, tidak mengkonsumsi obat

1. Ketepatan Klasifikasi

Ketepatan Klasifikasi dapat dilihat pada tabel 4. Untuk perhutungannya sebagai berikut. $A P E R=\frac{11+32}{142}=30,28$

Nilai APER menunjukkan kemungkinan kesalahan yang terjadi dalam klasifikasi machine learning CART adalah sebesar 30,28\%, artinya didapatkan peluang kesalahan yang terjadi dalam klasifikasi lansia yang mandiri diklasifikasikan menjadi lansia tidak mandiri ataupun sebaliknya lansia tidak mandiri/ketergantungan diklasifikasikan menjadi lansia mandiri adalah 30,28\%. 


$$
\text { Specivicity }=\frac{20}{31} \times 100 \%=64,52 \%
$$

Nilai specivicity menunjukkan nilai 64,52\% memiliki arti kemampuan machine learning CART untuk mengidentifikasi klasifikasi lansia yang tidak mandiri/ketergantungan ke dalam kelas tidak mandiri/ketergantungan adalah sebesar $64,52 \%$.

Sensitivity $=\frac{79}{111} \times 100 \%=71,17 \%$

Nilai sensitivity menunjukkan nilai 71,17\% memiliki arti kemampuan machine learning CART untuk mengidentifikasi klasifikasi lansia yang mandiri ke dalam kelas mandiri adalah sebesar $64,52 \%$.

$$
\text { Akurasi }=\frac{20+79}{142} \times 100 \%=69,72 \%
$$

Nilai akurasi menunjukkan nilai 69,72\% memiliki arti ketepatan machine learning CART untuk mengidentifikasi klasifikasi lansia yang mandiri dan tidak mandiri/ketergantungan ke dalam kelas mandiri dan tidak mandiri/ketergantungan adalah sebesar 69,72\%.

\section{PEMBAHASAN}

Pada penelitian ini Analisis CART sesuai untuk diterapkan pada klasifikasi kemandirian lansia, yang dibuktikan dengan nilai akurasi sebesar $69,72 \%$ di atas $50 \%$ dengan kemampuan CART untuk menempatkan kelompok lansia kategori tergantung ke dalam kelompok tergantung secara benar sebesar 64,52\% dan kemampuan CART untuk menempatkan kelompok lansia mandiri ke dalam kelompok mandiri secara benar sebesar 71,17\%. Pohon optimal yang dihasilkan sejumlah 5 pohon dengan 6 simpul terminal yang terdiri dari 4 simpul terminal kelas tidak mandiri dan 2 simpul terminal kelas mandiri. Kondisi tersebut sesuai dengan pendapat beberapa penelitian sebelumnya bahwa kelebihan CART adalah mampu mengklasifikasi data dalam jumlah besar, dengan hasil struktur pohon keputusan yang optimal, simpel, jelas dan mudah dipahami bahkan dapat juga digunakan untuk memprediksi, dengan hasil ketepatan klasifikasi dapat melebihi 50\%(Yin Loh, 2008); (Ramani, R.G. and Shanthi., S, 2012); (Munandar dan Winarko, 2015).

Faktor kesehatan yang memberikan kontribusi bagi kemandirian lansia diantaranya menu harian, persepsi kesehatan saat ini, perubahan fungsi pendengaran, gangguan muskuloskeletal dan konsumsi obat. Menu harian yang dikonsumsi lansia dan konsumsi atau penggunaan obat sesuai petunjuk medis merupakan faktor perilaku lansia dalam memelihara kesehatan yang dapat menunjang kualitas hidup lansia. Pola makan yang terjaga dan konsumsi obat sesuai dengan petunjuk medis merupakan hal yang berdampak pada peningkatan aktivitas dan kesehatan lansia. Meningkatnya kesehatan lansia dapat meningkatkan kualitas hidup lansia. Hal tersebut sesuai dengan yang dikemukakan oleh Prof Mukhoyur bahwa bagi lansia mengatur pola makan sehat dilakukan untuk menajga ketahanan tubuhnya di masa lanjut usia guna dapat menikmati hidup serta memiliki masa tua yang bahagia (Riady, 2014 dalam Siaputra, 2014). 
Persepsi kesehatan lansia merupakan faktor psikologis yang penting dalam menunjang kualitas hidup lansia. Persepsi kesehatan saat ini yang dimiliki lansia dapat menggambarkan peluang stress yang mungkin dialami lansia dalam kehidupannya saat ini. Persepsi lansia terhadap kondisi kesehatannya yang lebih baik saat ini menunjukkan bahwa lansia mampu beradaptasi terhadap perubahan-perubahan yang dialaminya saat ini. Hal tersebut sesuai dengan yang dikemukakan oleh Mc Grath bahwa stress adalah ketidakseimbangan antar kebutuhan fisik dan atau psikologisnya dan kemampuan merespon, yang dalam kondisi dimana seseorang tidak mampu memenuhi permintaan tersebut (Weinberg, 2003); (Siaputra, 2015).

\section{KESIMPULAN}

Hasil Analisis klassifikasi kemandirian hidup pada lansia menggunakan metode Classification And Regression Tree (CART) menghasilkan pohon klasifikasi optimal sejumlah 6 pohon dengan karakteriKondisi kesehatan memberikan kontribusi yang bermakna bagi pencapaian kemandirian lansia dalam kehidupannya. Beberapa kondisi kesehatan yang berkontribusi dalam kemandirian lansia di Kelurahan Kasin Wilayah Kerja Puskesmas Bareng Kabupaten Malang adalah menu harian yang dikonsumsi, persepsi kesehatan lansia saat ini, fungsi pendengaran, gangguan muskuloskeletal, dan konsumsi obat, dengan karakteristik lansia mandiri yang diperoleh adalah memiliki menu makan harian tertentu, memiliki fungsi pendengaran normal atau terganggu, memiliki persepsi kesehatan saat ini lebih baik, memiliki gangguan muskuloskeletal dan mengkonsumsi obat.

\section{DAFTAR PUSTAKA}

Ahlqvist, A., H. Nyfors, et al. (2016). "Factors associated with older people's independent living from the viewpoint of health and functional capacity: a register-based study." Nursing Open 2(39)

Beswick A.D., Gooberman-Hill R., Smith A., Wylde V.\& Ebrahim S, (2010). Maintaining Independence in Older People. Reviews in Clinical Gerontology.

Indonesia Survei Sosial Economic Nasional 2015 (Modul)

Lestari, M. W., I. W. Weta, et al. (2017). "Status gizi lansia berdasarkan pengetahuan dan aktivitas

fisik, di wilayah kerja Puskesmas Sukawati 1, Gianyar, Bali " JKK 4(2).

Munandar dan Winarko, (2015). "Regional Development Clasification Model Using Decision

Tree Approach.” International Journal of Computer Applications (0975-8887). Vol.114. Nomor.8

Pusat Data dan Informasi Lansia, (2017). Analisis Lansia. Kementerian Kesehatan Republik Indonesia.

Ramani, R.G., \& Shanti, S. (2021). Classifier Prediction Evaluation In Modeling Road Traffic Accident Data. In 2012 IEEE International Conference On Computational Intellegence and Computing Research. https://doi.org/10.1109/iccic.2012.6510289. 
Sumartini, S. H. and S. W. Purnami (2015). "Penggunaan Metode Classification and Regression Trees (CART) untuk Klasifikasi Rekurensi Pasien Kanker Serviks di RSUD Dr.Soetomo Surabaya." Jurnal Sains dan Seni ITS_4(2)

Sunu, U. F. S., G. Permadi, et al. (2017). "Hubungan Antara Aktivitas Fisik Dan Angka Kecukupan Gizi Makronutrien Terhadap Rasio Kolesterol Total/HDL Pada Masyarakat Pedesaan.” Jurnal Farmasi Sains Dan Komunitas, Mei 2017, 14(1):

Weinberg, S; Gould, D. (2003). Foundations of Sport and Exercise Psychology, $3^{\text {rd }}$ edition. Champaign, II: Human Kinetics.

Wibisono, F.E, Widjaja, A., Siaputra, H., Emmiati A. (2015). "Pola Perilaku Hidup Sehat Pra Lansia Dalam mengkonsumsi Makanan Sehari-Hari di Maureen Studio". Jurnal Hospitaly dan Manajemen Jasa. Vol.3 No.1 